\title{
Macroeconomic Policy Changes and Its Impact on Trade Unions, an Empirical Study on OECD Countries for the Period 2001-2020
}

\author{
Driton Qehaja, Genc Zhushi* \\ Faculty of Economics, University of Prishtina "Hasan Prishtina", Pristina 10000, Republic of Kosovo
}

Corresponding Author Email: Genc.Zhushi@uni-pr.edu

https://doi.org/10.18280/ijsdp.160818

Received: 27 September 2021

Accepted: 17 December 2021

\section{Keywords:}

macroeconomic factors, OECD, Trade union, unemployment

\begin{abstract}
This study examines the macroeconomic variables affecting trade union rate membership in OECD nations from 2001 to 2020. The Organization for Economic Cooperation and Development (OECD) has 38 of the most industrialized countries globally, which counts more than $80 \%$ of the global GDP; analyzing the macroeconomic movements of these countries means that we most likely know the variance of the global macroeconomic changes. We target the effect of employability, expenditure on education, unemployment, inflation, FDI, economic growth, wages, and salaries on trade union participation of employers. To conduct this research, we used data from World Bank, ILO, and OECD for 38 countries during the period 2001-2020, conducting a panel data Fixed Effect non-linear regression model with robust effect considering the non-normality and the possibility of heteroscedasticity of some of the variables. The results show that employers in the industry, the productivity in the service sector, and wages will increase the enrolment in a trade union, but on the other side, an increase of FDI and unemployment rates will decrease the association of employers to be in a trade union.
\end{abstract}

\section{INTRODUCTION}

The labourers' trade union plays a vital role in the state's economy, helping to better working conditions, making it an intriguing issue to research. Trade unions have always been about improving people's lives and ensuring social justice for everyone. Trade unions are fighting to safeguard workers and promote social justice for everyone, just as they were in the face of the Industrial Revolution's excesses, postwar destruction, and the battle for political freedom, as well as fights against authoritarian governments and apartheid.

Most union members participate in collective bargaining, which is a negotiation process between employers and a group of employees to reach agreements to manage working pay, working conditions, benefits, and other aspects of workers' compensation and rights [1]. The weight of salaries, working hours, training, health and safety, overtime and grievance processes, and the opportunity to participate in corporate concerns are all frequently defined in these collective agreements.

Coordination via collective bargaining is acknowledged as a critical predictor of labour market outcomes, productivity and macroeconomic performance. If unions boost employees' pay, one may predict negative consequences on employment levels and job security. However, if unions only boost pay to the level of employees' productivity or enhance levels of workplace efficiency, the impact on employment may be minimal or even positive.

Regarding productivity, there are many channels by which unions could, in theory, affect productivity, whether measured in terms of sales per employee, value-added, or their qualityadjusted equivalents. The literature has assumed that unions' "voice" face can be productive. For instance, it may improve the quality of information managers use to make decisions. Similarly, it is considered that the "monopoly" face employed by unions to negotiate for higher pay might be harmful to business performance, at least in terms of profitability. Union bargaining for higher pay, on the other hand, may be beneficial to company productivity since, all else being equal, higher salaries can recruit and retain more productive employees while also motivating them to work harder. Furthermore, by reducing the likelihood of employees quitting, unions may be able to encourage employers to spend more in human capital, resulting in increased productivity.

Although trade unions impose a high cost on an economy, one method of trade unionism allows the union to contribute to economic progress. This macro-focused kind of unionism necessitates strong collaboration between the trade union and the governing party to contribute to economic growth.

Many econometric studies of the economic impact of unions have been undertaken for OECD nations, in which the relevance of unions in determining different economic outcomes in these countries has been thoroughly investigated. This study uses data from 38 OECD countries to look at the syndical variation in economic performance in those countries. Given the importance of employee unionization, it's important to remember that the term "trade union" refers to a membership-based organization whose members are mostly workers. The following research topics are discussed in this article: how employment in various economic sectors affects trade union rates; how government spending at various levels of education affects trade union memberships; how inflation, FDI, and economic growth affect the trade union; and how much unemployment and wages affect the trade union. 


\section{LITERATURE REVIEW}

Despite substantial research on trade unions, there has been little research on the influence of macroeconomic policies on trade unions. Concerning the influence of the union rate on a nation's unemployment [2], it has been found that states with the highest unionization density had a natural unemployment rate increase in the 1980s. Second, according to Turnbull's 2003 national estimates, rising worker unionization "costs" the economy a decrease in Gross Domestic Product (GDP) percentage [3]. Furthermore, Ramjes [4] asserts that a rise in trade union rates would reduce worker productivity (Ramjas 1989). The effect of a country's trade union rate on inflation growth demonstrates that union density influences inflation growth. According to Oswald [5], the union raises wages, decreases employment and output, and can boost or decrease overall work income $[5,6]$.

The impact of labour market institutions on growth and unemployment is the subject of recent research. It includes a plethora of information regarding the institutions of the labour market. A critical summary of the results obtained in empirical studies explaining either growth or unemployment and their interrelationships, both of which are presented in this volume, is also included, as are regressions that explain growth and unemployment based on data captured by labor market institutions and from international data sources [7]. According to another research, the following labour market institutions are taken into account: Labor taxes, rules and regulations governing employee rights, trade unions and pay structure, the social security system (in general), education and training, and regional labour mobility restrictions [8].

According to research by Groot, by incorporating labor market institutions, 2001 cross-cutting regressions lower unemployment (both short and long-term) and productivity growth. This study looked at 20 OECD countries and two time periods: 1983-1988 and 1989-1994. To examine impacts on labor market institutions, no extra conditional variables were added in their regressions (mainly aimed at providing an overview of the correlations between the data collected). Unemployment, savings rates, population growth, and other economic development indicators, for example, do not regress growth rates. Similarly, the unemployment rate in the United States is not regressed on product competitiveness, growth rate, or productivity at the start of the period. These studies suggest that high taxes, generous social security systems, and strong unions increase unemployment in collaboration with businesses. In the labor market, the links between growth and institutions are weak. Some shaky evidence suggests that job protection has a favourable upward influence, but that total labor taxation negatively impacts. Wage inflation will not rise if higher salaries compensate for higher productivity. Furthermore, inflation will rise if wages rise without boosting productivity [9].

Daveri [10] looked at the effects of taxes on employment and growth. According to this research, excessive taxes are passed on to workers, increasing labor costs and causing unemployment in syndicates. Furthermore, high wage costs result in high capital-labor ratios, lower investment returns, and restricted economic development. They test their hypothesis that high-tax countries have low growth and large jobless rates. The tests were based on a panel of 14 OECD countries from 1965 to 1991. (divided into five sub-periods of equal length). Their results are compatible with theoretical assumptions and are relatively robust in assessment technology, both quantitatively and qualitatively. They discover a negative association between GDP per capita growth and unemployment after accounting for changes in adequate capital and labor tax rates. Increased labor taxes are also connected to higher unemployment and slower economic growth. A 9.4\% increase in the effective labor tax rate has resulted in a 0.5 percentage point decrease in yearly growth and a $4 \%$ increase in unemployment [10].

Most research on trade unions and investment begins with theoretical work on holding and explores whether unions diminish investment. Addison, 1989, published a detailed literature assessment on the influence of labor unions on productivity, profitability, and growth. They are backed up by research on rent-seeking unions, demonstrating that they may reduce employers' spending in physical capital, R\&D, and other high-risk activities. As a result, productivity growth in integrated enterprises and industries has been relatively moderate [11]. Bean's 1995 results were later confirmed using panel regression data spanning 137 industries and eight time periods. For example, to capture the impacts of competition, the rate of increase in capital stock, concentration ratios, and import penetration are all included as independent variables. As independent variables, they also contain factors that represent the influence of industrial relations, such as union recognition and the existence of various trade unions. They make the important conclusion that the establishment of trade unions has a major negative influence on total factor productivity. The total factor productivity growth of many unionized jobs is around one percentage point lower than that of non-unionized occupations. In our area of expertise, no significant growth effects have been observed based on crosssectional study on the effects of unions [12].

Reenen, 1996 and Wrigley, 2002 take a different approach to the relationship between labor market institutions and development than earlier research. After questioning various British businesses, they uncover confirmation of the need of rent sharing. Their findings show that creative businesses often pay greater salaries, while competitive innovations pay lower wages. This information might be seen as evidence that corporations are deliberately dispersing rents to boost productivity. Theoretical models of efficiency pay may be used to explain why this tendency occurs. This study is important because it demonstrates one of the most serious problems empirical research faces [13, 14]. Higher wages will result from strong unions limiting $R \& D$ expenditure and delaying growth, according to Aldcroft, 2000, while higher pay may result from the separation of leases from fast-growing businesses that are successful at innovating [15].

Higher unionization rates may positively influence equilibrium inflation by boosting the equilibrium real wage and unemployment due to their monopolistic control over labor supply. Consequently, central bankers that are less hawkish will be more willing to pursue expansionary monetary policy. According to Motyovszki's article, when wage-bargainers grow more aware of the unfavorable macroeconomic consequences of the demands they make, unions with above-average bargaining coordination may negate the good effect of union density. Unionization has a less influence in wealthier countries, maybe because real wages are already high in these countries, and unions are less engaged in collective bargaining [16]. Although the results stand up to numerous endogeneity tests, they vary from Bowdler and Nunziata, 2007 found at various stages in their analysis. This might be due to differences in the data used, but regardless of 
the data used, the core outcome of a positive influence of unionization stays the same [6].

Between 1983 and 1996, increased foreign investment in US manufacturing sectors was inversely related with the pay premium enjoyed by union members [17]. To understand the implicit threat impact of FDI, academics focus on the bargaining result rather than the change in the relative demand for unskilled labor for the first time. According to prior research, the need for skilled employees in the United States is moving, and this transition is being fueled by trade, outsourcing, and technological developments [6].

From an empirical approach, distinguishing between distinct hypotheses is a challenging task. Only a modest amount of empirical research on the link between growth and unemployment and how labor market institutions contribute to the establishment of this relationship has been done too far. It's difficult to put ideas to the test because of their complicated ramifications. This is the context in which we've offered the following hypotheses, which are based on the research we did for this study [2-4, 6, 18-26].

Table 1. Hypothesis and variables

\begin{tabular}{|c|c|c|c|c|}
\hline Hypothesis & Variable name & Measurement & $\begin{array}{l}\text { Variable } \\
\text { Code }\end{array}$ & Source \\
\hline $\begin{array}{l}H 1 \text { : Increasing the Employers in } \\
\text { the Agriculture sector will } \\
\text { increase the percentage of } \\
\text { members in the trade unions. }\end{array}$ & $\begin{array}{l}\text { Employment in } \\
\text { agriculture }\end{array}$ & $\begin{array}{l}\text { \% of total } \\
\text { employment } \\
\text { (modeled ILO } \\
\text { estimate) }\end{array}$ & $e a$ & $\begin{array}{l}\text { International Labour Organization, } \\
\text { ILOSTAT database. Data retrieved on } \\
\text { January 29, } 2021 .\end{array}$ \\
\hline $\begin{array}{l}\text { H2: Increasing the Employers in } \\
\text { Industry (Manufacturing) sector } \\
\text { will increase the percentage of } \\
\text { members in the trade unions. }\end{array}$ & $\begin{array}{l}\text { Employment in } \\
\text { industry }\end{array}$ & $\begin{array}{l}\text { \% of total } \\
\text { employment } \\
\text { (modeled ILO } \\
\text { estimate) }\end{array}$ & $e i$ & $\begin{array}{l}\text { International Labour Organization, } \\
\text { ILOSTAT database. Data retrieved on } \\
\text { January 29, } 2021 .\end{array}$ \\
\hline $\begin{array}{l}H 3 \text { : Increasing the Employers in } \\
\text { the Service sector will increase } \\
\text { the percentage of members in } \\
\text { the trade unions. }\end{array}$ & $\begin{array}{l}\text { Employment in } \\
\text { services }\end{array}$ & $\begin{array}{l}\text { \% of total } \\
\text { employment } \\
\text { (modeled ILO } \\
\text { estimate) } \\
\end{array}$ & es & $\begin{array}{l}\text { International Labour Organization, } \\
\text { ILOSTAT database. Data retrieved on } \\
\text { January 29, } 2021 .\end{array}$ \\
\hline $\begin{array}{l}H 4: \text { An increase in expending in } \\
\text { primary education will increase } \\
\text { the percentage of members in } \\
\text { the trade unions. }\end{array}$ & $\begin{array}{l}\text { Expenditure on } \\
\text { primary education }\end{array}$ & $\begin{array}{l}\% \text { of government } \\
\text { expenditure on } \\
\text { education }\end{array}$ & epe & $\begin{array}{c}\text { UNESCO Institute for Statistics } \\
\text { (http://uis.unesco.org/). Data as of February } \\
2020 .\end{array}$ \\
\hline $\begin{array}{l}\text { H5: An increase in expending in } \\
\text { secondary education will } \\
\text { increase the percentage of } \\
\text { members in the trade unions. }\end{array}$ & $\begin{array}{c}\text { Expenditure on } \\
\text { secondary education }\end{array}$ & $\begin{array}{l}\% \text { of government } \\
\text { expenditure on } \\
\text { education }\end{array}$ & ese & $\begin{array}{c}\text { UNESCO Institute for Statistics } \\
\text { (http://uis.unesco.org/). Data as of February } \\
2020 .\end{array}$ \\
\hline $\begin{array}{l}\text { H6: An increase in expending in } \\
\text { tertiary education will increase } \\
\text { the percentage of members in } \\
\text { the trade unions. }\end{array}$ & $\begin{array}{l}\text { Expenditure on } \\
\text { tertiary education }\end{array}$ & $\begin{array}{l}\% \text { of government } \\
\text { expenditure on } \\
\text { education }\end{array}$ & ete & $\begin{array}{l}\text { UNESCO Institute for Statistics } \\
\text { (http://uis.unesco.org/). Data as of February } \\
2020 .\end{array}$ \\
\hline $\begin{array}{l}H 7: \text { An increase in Foreign } \\
\text { Direct Investment will increase } \\
\text { the percentage of members in } \\
\text { the trade unions. }\end{array}$ & $\begin{array}{l}\text { Foreign direct } \\
\text { investment, net } \\
\quad \text { inflows }\end{array}$ & $\%$ of GDP & $f d i$ & $\begin{array}{c}\text { International Monetary Fund, International } \\
\text { Financial Statistics and Balance of Payments } \\
\text { databases, World Bank, International Debt } \\
\text { Statistics, and World Bank and OECD GDP } \\
\text { estimates. }\end{array}$ \\
\hline $\begin{array}{l}H 8: \text { Increasing GDP Deflator } \\
\text { will increase the percentage of } \\
\text { members in the trade unions. }\end{array}$ & GDP deflator & $\begin{array}{l}\text { base year varies } \\
\text { by country }\end{array}$ & $g d p d$ & $\begin{array}{l}\text { World Bank national accounts data, and } \\
\text { OECD National Accounts data files. }\end{array}$ \\
\hline $\begin{array}{l}H 9: \text { If GDP growth increases, } \\
\text { the percentage of members in } \\
\text { the trade unions will be greater. }\end{array}$ & GDP growth & annual $\%$ & $g d p g$ & $\begin{array}{l}\text { World Bank national accounts data, and } \\
\text { OECD National Accounts data files. }\end{array}$ \\
\hline $\begin{array}{l}\text { H10: Higher inflation will } \\
\text { increase the percentage of } \\
\text { members in the trade unions. }\end{array}$ & $\begin{array}{l}\text { Inflation, GDP } \\
\text { deflator }\end{array}$ & annual $\%$ & $i g d p d$ & $\begin{array}{l}\text { World Bank national accounts data, and } \\
\text { OECD National Accounts data files. }\end{array}$ \\
\hline $\begin{array}{l}\text { H11: The increase of value } \\
\text { added per worker in Agriculture } \\
\text { is likely to increase the } \\
\text { percentage of members in the } \\
\text { trade unions. }\end{array}$ & $\begin{array}{l}\text { Agriculture, forestry, } \\
\text { and fishing, value } \\
\text { added }\end{array}$ & $\%$ of GDP & ave & $\begin{array}{l}\text { World Bank national accounts data, and } \\
\text { OECD National Accounts data files. }\end{array}$ \\
\hline $\begin{array}{l}\text { H12: The increase of value } \\
\text { added per worker in } \\
\text { Manufacture is likely to increase } \\
\text { the percentage of members in } \\
\text { the trade unions. }\end{array}$ & $\begin{array}{l}\text { Manufacturing, value } \\
\text { added }\end{array}$ & $\%$ of GDP & $m v a$ & $\begin{array}{l}\text { World Bank national accounts data, and } \\
\text { OECD National Accounts data files. }\end{array}$ \\
\hline $\begin{array}{l}\text { H13: The increase of value } \\
\text { added per worker in Service is } \\
\text { likely to increase the percentage } \\
\text { of members in the trade unions. }\end{array}$ & Services, value added & $\%$ of GDP & svag & $\begin{array}{l}\text { World Bank national accounts data, and } \\
\text { OECD National Accounts data files. }\end{array}$ \\
\hline
\end{tabular}




\begin{tabular}{|c|c|c|c|c|}
\hline Hypothesis & Variable name & Measurement & $\begin{array}{c}\text { Variable } \\
\text { Code }\end{array}$ & Source \\
\hline $\begin{array}{l}\text { H14: If there is an increase in } \\
\text { Unemployment with primary } \\
\text { education, the percentage of } \\
\text { members in the trade unions will } \\
\text { be decreased. }\end{array}$ & $\begin{array}{l}\text { Unemployment with } \\
\text { basic education }\end{array}$ & $\begin{array}{l}\% \text { of total labor } \\
\text { force with basic } \\
\text { education }\end{array}$ & ube & $\begin{array}{l}\text { International Labour Organization, } \\
\text { ILOSTAT database. Data retrieved on } \\
\text { January 29, } 2021 .\end{array}$ \\
\hline $\begin{array}{l}\text { H15: If there is an increase in } \\
\text { unemployment with secondary } \\
\text { education, the percentage of } \\
\text { members in the trade unions will } \\
\text { decrease. }\end{array}$ & $\begin{array}{l}\text { Unemployment with } \\
\text { intermediate } \\
\text { education }\end{array}$ & $\begin{array}{l}\% \text { of total labor } \\
\text { force with } \\
\text { intermediate } \\
\text { education }\end{array}$ & uie & $\begin{array}{c}\text { International Labour Organization, } \\
\text { ILOSTAT database. Data retrieved on June } \\
15,2021 .\end{array}$ \\
\hline $\begin{array}{l}\text { H16: If there is an increase in } \\
\text { Unemployment with tertiary } \\
\text { education, the percentage of } \\
\text { trade union members will } \\
\text { decrease. }\end{array}$ & $\begin{array}{l}\text { Unemployment with } \\
\text { advanced education }\end{array}$ & $\begin{array}{l}\% \text { of total labor } \\
\text { force with } \\
\text { advanced } \\
\text { education }\end{array}$ & uae & $\begin{array}{l}\text { International Labour Organization, } \\
\text { ILOSTAT database. Data retrieved on } \\
\text { January 29, } 2021 .\end{array}$ \\
\hline $\begin{array}{c}\text { H17: An increase in total } \\
\text { Unemployment will increase the } \\
\text { percentage of members in the } \\
\text { trade unions. }\end{array}$ & Unemployment, total & $\begin{array}{l}\% \text { of total labor } \\
\text { force (modeled } \\
\text { ILO estimate) }\end{array}$ & utilo & $\begin{array}{l}\text { International Labour Organization, } \\
\text { ILOSTAT database. Data retrieved on } \\
\text { January 29, } 2021 .\end{array}$ \\
\hline $\begin{array}{l}\text { H18: Higher wages will } \\
\text { motivate an increase in the } \\
\text { percentage of members in the } \\
\text { trade unions. }\end{array}$ & $\begin{array}{l}\text { Wage and salaried } \\
\text { workers, total (\% of } \\
\text { total employment) }\end{array}$ & $\begin{array}{l}\text { modeled ILO } \\
\text { estimate }\end{array}$ & $w s w$ & $\begin{array}{l}\text { International Labour Organization, } \\
\text { ILOSTAT database. Data retrieved on } \\
\text { January 29, } 2021 .\end{array}$ \\
\hline Depended Variable & $\begin{array}{c}\text { Trade Union } \\
\text { members }\end{array}$ & $\begin{array}{l}\text { Percentage of } \\
\text { employees }\end{array}$ & tupe & OECD stat \\
\hline
\end{tabular}

Testing these assumptions will give insight into how countries' economies effect worker unionization. From the hypothesis of Table 1 a regression analysis will be undertaken to quantify the influence of macroeconomic variables on trade unions in the OECD nations for the years 2001 to 2020, the latest updated data released by the World Bank and the International Labor Organization, as secondary data. e International Labor Organization, as secondary data.

\section{DATA DESCRIPTION}

The statistics collected in this article are from secondary sources, mainly from OECD, World Bank, and the International Labor Organization (ILO). We utilized panel data, which acquired many statistical units across various periods, with the same periods and statistical units. More precisely, 38 countries were seized during the same 20-year period. Australia, Austria, Belgium, Canada, Chile, Colombia, Costa Rica, Czech Republic, Denmark, Estonia, Finland, France, Germany, Greece, Hungary, Iceland, Ireland, Israel, Italy, Japan, Korea Republic, Latvia, Lithuania, Luxembourg, Mexico, Netherlands, New Zealand, Norway, Poland,
Portugal, Slovak Republic, Slovenia, Spain, Sweden, Switzerland, Turkey, United Kingdom, United States are the countries or units covered in this document. The OECD has chosen these nations intentionally, given that they provide annual data, specifically for the period 2001-2020.

The data are examined using descriptive statistics, including arithmetic mean, standard deviation, minimum and maximum values, Variance, Kurtosis and Skewness, and the t-test, to measure the distribution of the data, adding here a basic linear regression model, to measure the relationship between variables. From these data, we have conducted five models with different rearrangements of the independent variables as is presented in Table 2 .

Analyzing the descriptive statistics from Table 2 presents the problem of non-normality for some variables. The main parts of the distribution are Kurtosis and Skewness, but also another important part is the Standard Deviation. The number of observations depends on the secondary data available on World Bank, ILO, and the OECD web page. From Table 2, we can see that this number differs from different variables; this significantly influenced our econometric models, forcing us to remove some variables and focus on those with higher observations.

Table 2. Describing data and variables

\begin{tabular}{|c|c|c|c|c|c|c|c|c|c|}
\hline & Observation & Mean & Variance & Standard Deviation & Kurtosis & Skewness & Min & $\operatorname{Max}$ & t-value \\
\hline$e a$ & 722 & 6.328 & 28.049 & 5.296 & 4.802 & 1.486 & .680 & 27.140 & 32.105 \\
\hline$e i$ & 722 & 24.492 & 32.494 & 5.700 & 3.22 & .673 & 10.76 & 40.530 & 115.449 \\
\hline es & 722 & 69.182 & 67.66 & 8.226 & 2.442 & -.343 & 46.35 & 88.510 & 225.992 \\
\hline epe & 424 & 27.000 & 58.991 & 7.681 & 2.275 & .053 & 12.533 & 48.325 & 72.384 \\
\hline ese & 424 & 38.124 & 39.53 & 6.287 & 2.541 & .248 & 25.201 & 56.446 & 124.859 \\
\hline ete & 450 & 22.847 & 23.936 & 4.892 & 2.753 & .411 & 12.596 & 36.812 & 99.061 \\
\hline$f d i$ & 718 & 5.154 & 100.659 & 10.033 & 24.583 & 3.856 & -28.307 & 86.589 & 13.764 \\
\hline gdpd & 759 & 92.738 & 338.027 & 18.386 & 26.042 & 2.283 & 29.764 & 279.916 & 138.964 \\
\hline gdpg & 759 & 2.154 & 11.78 & 3.432 & 8.596 & -.621 & -14.839 & 25.176 & 17.289 \\
\hline igdpd & 755 & 2.634 & 7.564 & 2.75 & 6.894 & 1.326 & -9.728 & 16.485 & 26.319 \\
\hline ave & 751 & 2.62 & 3.415 & 1.848 & 5.105 & 1.470 & .214 & 10.191 & 38.847 \\
\hline$m v a$ & 750 & 14.755 & 24.262 & 4.926 & 3.959 & .628 & 3.761 & 36.623 & 82.037 \\
\hline
\end{tabular}




\begin{tabular}{cccccccccc}
\hline & Observation & Mean & Variance & Standard Deviation & Kurtosis & Skewness & Min & Max & t-value \\
\hline svag & 751 & 62.663 & 39.535 & 6.288 & 2.505 & .224 & 47.21 & 80.084 & 273.111 \\
\hline uae & 683 & 4.836 & 8.325 & 2.885 & 8.607 & 2.044 & .830 & 20.400 & 43.799 \\
\hline uie & 678 & 8.139 & 21.325 & 4.618 & 6.263 & 1.564 & 1.020 & 31.150 & 45.891 \\
\hline ube & 666 & 13.144 & 63.623 & 7.976 & 7.625 & 1.909 & 2.430 & 53.170 & 42.525 \\
\hline utilo & 760 & 7.621 & 16.268 & 4.033 & 6.886 & 1.700 & 1.810 & 27.470 & 52.086 \\
\hline $\boldsymbol{w s w}$ & 722 & 82.032 & 94.563 & 9.724 & 5.371 & -1.588 & 46.450 & 93.910 & 226.668 \\
\hline tupe & 634 & 27.766 & 430.978 & 20.76 & 4.14 & 1.446 & 4.500 & 93.300 & 33.676 \\
\hline \multicolumn{7}{c}{ Source: World Bank, World Development Indicators; International Labor Organization (ILO); OECD. }
\end{tabular}

The first three variables (ea, ei, es) in Table 2, measuring the employment in Agriculture, Industry, and Service, have a relatively low Standard Deviation compared to the Mean; also the Kurtosis and Skewness parameters are well within the thresholds, presenting the data as reasonably normal. The next group (epe, ese, ete), which represents the Expenditure on Primary, Secondary and Tertiary education, have also low Standard Deviation and close to zero Kurtosis and Skewness, presenting a relatively normal distribution of the data. The variables $f d i$ and $g d p d$ tend to have a high Standard Deviation. Other parameters point to the no-normality of the distribution of these data, presenting the possibility of transforming these variables into the natural logarithmic form, altering the distribution of the data to a more normal shape. Analyzing $g d p g$ and igdpd for measuring the growth rate and inflation rate for the distribution of the pattern data, it is clear that we do not have any problems with non-normality.

Grouping the variables (ave, mva, svag) in Table 2 representing the value-added per worker in Agriculture, Manufacture and Service sectors do have some minor issues with non-normality of the data but not something that could alter the results, but in any case, we have conducted some models in which we have transferred these variables into the natural logarithmic form (See Model 4 in the econometric results Table 3). Furthermore, the last group of independent variables (uae, uie, ube, utilo, wsw) refers to Unemployment in Agriculture, manufacturing, and Service, unemployment, and the total Wages and Salaries do not show a not-normality distribution of their data. Lastly, the dependent variable (in our models) tupe has relatively significant Standard Deviation, Kurtosis, and Skewness parameters, shoving patterns of nonormality of the data, even though these tendencies are not fairly server, to answer this tendency, we have used the natural logarithmic form in some econometric models.

\section{RESEARCH METHODOLOGY}

This research analyzes the relationship between macroeconomic factors and trade unions using secondary World Bank ILO and OECD data. Some of the data were not normally distributed, and we have transformed them into the natural logarithmic form; using the knowledge for panel data for this analysis, we have used non-linear panel data regression analysis imputed through STATA-16 software packet.

Analyzing individual-specific effect panel models with the dependent variable $y_{i t}$ defines the formula:

$$
y_{i t}=\alpha_{i}+x_{i t}^{\prime} \beta+\epsilon_{i t}
$$

where, $x_{i t}$ are the regressors, $\alpha_{i}$ are the random individual effects and $\epsilon_{i t}$ is the idiosyncratic error. In this paper, we used the Fixed Effect (FE) for every model, and with the FE model $\alpha_{i}$ is relatively permitted to be correlated with the regressor $x_{i t}$, where it gives us a limited form of endogeneity. Analyzing the error term $\vartheta_{i t}=\alpha_{i}+\epsilon_{i t}$ and engage $x_{i t}$ to be correlated with the time-invariant component of the error $\alpha_{i}$, while assuming that $x_{i t}$ is uncorrelated with the idiosyncratic error $\epsilon_{i t}$.

The FE models signify that $E\left(y_{i t} \mid \alpha_{i}, x_{i t}\right)=\alpha_{i}+x_{i t}^{\prime} \beta$, assuming $E\left(\epsilon_{i t} \mid \alpha_{i}, x_{i t}\right)=0$, thus $\beta_{j}=\partial E\left(y_{i t} \mid \alpha_{i}, x_{i t}\right) / \partial x_{j, i t}$. The data showed some levels of Kurtosis and Skewness presenting with the assumption of non-normality, more specifically $E\left(\epsilon_{i t} \epsilon_{j s}\right)=0$ for $i \neq j, E\left(\epsilon_{i t} \epsilon_{j s}\right)$ is unrestricted, and $\epsilon_{i t}$ is heteroscedastic, thus we have used the robust standard errors for all the models.

In order to measure the impact of macroeconomic factors on the trade union members, five models have been constructed from the mathematical formals and data presented in this paper. All the models use robust standard errors to exclude the heteroscedasticity and non-normality problems. For different models' different variables have been considered to build up an adequate model. In all cases, the dependent variable (tupe) is the percentage of employers in unions, but for models 3,4 , and 5, this variable has been transformed into the natural logarithmic form for non-normality problems.

From Table 3, which represents all the econometric results, Model 1 takes only non-transformed variables (we have used the original dataset). However, we have excluded the expenditure on three levels of the education group of variables because they had fewer observations. Model 2 uses some transferred variables into the natural logarithmic form (All the variables that have $\mathrm{LN}$ in front are natural logarithm transformation) based on the non-normality distribution presented by the parameters of Kurtosis and Skewness. Furthermore, Model 3 uses the same independent variables, but the only difference is that the dependent variable (tupe) has been transformed into the natural logarithm form. Model 4 uses all transformed variables, including the dependent variable. Model 5 is based on Model 1 but includes the expenditure on three levels of the education group of variables.

\section{EMPIRICAL RESULTS}

We obtained the findings shown in Table 3 using the statistical program STATA-16, the data studied in this research, econometric panel data models with robust standard errors, and some transformation of the variables into their natural logarithmic form. Model 1 received the most observations, followed by the rest. The determination coefficient is above the mean, putting our models in an excellent position to explain more than half of the variation in the dependent variable. Furthermore, the likelihood of the F statistics reveals that all of the independent factors are significant and have an important influence on trade union members. Because the p-value of the Hausman test was less than 0.01 for all models, Fixed Effect modeling was employed. 
Table 3. Regression results

\begin{tabular}{|c|c|c|c|c|c|}
\hline$e a$ & $\begin{array}{c}\text { Model 1 } \\
\text { tupe } \\
2.332 \\
(21.17) \\
\end{array}$ & $\begin{array}{c}\text { Model } 2 \\
\text { tupe } \\
-12.846 \\
(21.51) \\
\end{array}$ & $\begin{array}{c}\text { Model 3 } \\
\text { LNtupe } \\
-0.271 \\
(1.032) \\
\end{array}$ & $\begin{array}{l}\text { Model } 4 \\
\text { LNtupe }\end{array}$ & $\begin{array}{c}\text { Model 5 } \\
\text { LNtupe } \\
-17.861 \\
(19.89) \\
\end{array}$ \\
\hline$e i$ & $\begin{array}{c}2.931 \\
(21.12)\end{array}$ & $\begin{array}{l}-12.571 \\
(21.49) \\
\end{array}$ & $\begin{array}{c}-0.269 \\
(1.033)\end{array}$ & & $\begin{array}{l}-17.477 \\
(19.84) \\
\end{array}$ \\
\hline es & $\begin{array}{c}1.854 \\
(21.14) \\
\end{array}$ & $\begin{array}{r}-13.442 \\
(21.51) \\
\end{array}$ & $\begin{array}{c}-0.311 \\
(1.033) \\
\end{array}$ & & $\begin{array}{r}-18.345 \\
(19.87) \\
\end{array}$ \\
\hline$f d i$ & $\begin{array}{l}-0.010 \\
(0.019) \\
\end{array}$ & & & & $\begin{array}{l}-0.05^{* *} \\
(0.022) \\
\end{array}$ \\
\hline gdpd & $\begin{array}{l}-0.006 \\
(0.020)\end{array}$ & & & & $\begin{array}{c}-0.022 \\
(0.037) \\
\end{array}$ \\
\hline gdpg & $\begin{array}{c}0.044 \\
(0.043) \\
\end{array}$ & $\begin{array}{c}0.004 \\
(0.034) \\
\end{array}$ & $\begin{array}{l}0.005^{*} \\
(0.002) \\
\end{array}$ & & $\begin{array}{l}0.07 * * \\
(0.032) \\
\end{array}$ \\
\hline$i g d p d$ & $\begin{array}{c}0.017 \\
(0.083) \\
\end{array}$ & $\begin{array}{c}0.042 \\
(0.087) \\
\end{array}$ & $\begin{array}{l}0.008^{*} \\
(0.005)\end{array}$ & & $\begin{array}{l}-0.026 \\
(0.073) \\
\end{array}$ \\
\hline ave & $\begin{array}{l}-0.381 \\
(0.371) \\
\end{array}$ & $\begin{array}{l}-0.295 \\
(0.591) \\
\end{array}$ & $\begin{array}{l}-0.041 \\
(0.027) \\
\end{array}$ & & $\begin{array}{c}0.139 \\
(0.545) \\
\end{array}$ \\
\hline$m v a$ & $\begin{array}{l}0.26^{* *} \\
(0.127) \\
\end{array}$ & $\begin{array}{l}0.35^{* *} \\
(0.152) \\
\end{array}$ & $\begin{array}{c}0.008 \\
(0.005) \\
\end{array}$ & & $\begin{array}{l}0.300^{*} \\
(0.154) \\
\end{array}$ \\
\hline svag & $\begin{array}{c}0.552 * * * \\
(0.160)\end{array}$ & $\begin{array}{c}0.683^{* * * *} \\
(0.192)\end{array}$ & $\begin{array}{c}0.037 * * * \\
(0.010)\end{array}$ & & $\begin{array}{c}0.560 * * * \\
(0.148)\end{array}$ \\
\hline uae & $\begin{array}{c}-0.902 * * * \\
(0.302) \\
\end{array}$ & & & & $\begin{array}{c}-1.154 * * * \\
(0.299) \\
\end{array}$ \\
\hline uie & $\begin{array}{c}-0.242 \\
(0.295) \\
\end{array}$ & & & & $\begin{array}{c}-0.225 \\
(0.245) \\
\end{array}$ \\
\hline ube & $\begin{array}{c}-0.259^{* *} \\
(0.105) \\
\end{array}$ & & & & $\begin{array}{c}-0.300^{* * * *} \\
(0.107) \\
\end{array}$ \\
\hline utilo & $\begin{array}{c}.490 * * * \\
(0.391) \\
\end{array}$ & & & & $\begin{array}{c}1.559^{* * *} * \\
(0.366) \\
\end{array}$ \\
\hline$w s w$ & $\begin{array}{c}0.265^{*} \\
(0.138) \\
\end{array}$ & & & & $\begin{array}{l}0.349 * \\
(0.181) \\
\end{array}$ \\
\hline LNfdi & & $\begin{array}{c}-0.108 \\
(0.125) \\
\end{array}$ & $\begin{array}{c}-0.008^{*} \\
(0.005) \\
\end{array}$ & $\begin{array}{l}-0.005 \\
(0.006) \\
\end{array}$ & \\
\hline LNgdpd & & $\begin{array}{l}-1.169 \\
(2.270) \\
\end{array}$ & $\begin{array}{l}-0.163 \\
(0.143) \\
\end{array}$ & $\begin{array}{c}-0.093 \\
(0.146) \\
\end{array}$ & \\
\hline LNuae & & $\begin{array}{l}-4.13 * * \\
(1.717) \\
\end{array}$ & $\begin{array}{c}-0.131^{*} \\
(0.076)\end{array}$ & $\begin{array}{l}-0.110 \\
(0.070)\end{array}$ & \\
\hline LNuie & & $\begin{array}{c}-4.656 \\
(2.791) \\
\end{array}$ & $\begin{array}{c}-0.21 * * \\
(0.100) \\
\end{array}$ & $\begin{array}{l}-0.165^{*} \\
(0.085)\end{array}$ & \\
\hline LNube & & $\begin{array}{l}-6.1 * * * \\
(2.100) \\
\end{array}$ & $\begin{array}{l}-0.120 \\
(0.091) \\
\end{array}$ & $\begin{array}{l}-0.086 \\
(0.092) \\
\end{array}$ & \\
\hline LNutilo & & $\begin{array}{l}16.4 * * * \\
(4.075)\end{array}$ & $\begin{array}{l}0.6 * * * \\
(0.208)\end{array}$ & $\begin{array}{l}0.51 * * \\
(0.188)\end{array}$ & \\
\hline$L N w s w$ & & $\begin{array}{l}20.825 \\
(13.11) \\
\end{array}$ & $\begin{array}{c}1.167 \\
(0.767) \\
\end{array}$ & $\begin{array}{l}1.52 * * \\
(0.745) \\
\end{array}$ & \\
\hline LNea & & & & $\begin{array}{l}0.162^{*} \\
(0.096)\end{array}$ & \\
\hline$L N e i$ & & & & $\begin{array}{c}0.162 \\
(0.306) \\
\end{array}$ & \\
\hline LNes & & & & $\begin{array}{c}-2.1 * * * \\
(0.778) \\
\end{array}$ & \\
\hline LNgdpg & & & & $\begin{array}{c}0.003 \\
(0.009)\end{array}$ & \\
\hline LNigdpd & & & & $\begin{array}{l}0.017^{*} \\
(0.009) \\
\end{array}$ & \\
\hline LNave & & & & $\begin{array}{l}-0.070 \\
(0.065)\end{array}$ & \\
\hline LNmva & & & & $\begin{array}{c}0.019 \\
(0.098) \\
\end{array}$ & \\
\hline LNsvag & & & & $\begin{array}{c}1.909 * * * \\
(0.545)\end{array}$ & \\
\hline epe & & & & & $\begin{array}{c}-0.123 \\
(0.104) \\
\end{array}$ \\
\hline ese & & & & & $\begin{array}{c}0.054 \\
(0.058)\end{array}$ \\
\hline ete & & & & & $\begin{array}{c}0.173 * \\
(0.087)\end{array}$ \\
\hline
\end{tabular}




\begin{tabular}{cccccc}
\hline & Model 1 & Model 2 & Model 3 & Model 4 & Model 5 \\
\hline Constant & -246.48 & 1210.6 & 25.884 & -3.097 & 1769.7 \\
& $(2114)$ & $(2145)$ & $(104)$ & $(3.96)$ & $(1983)$ \\
\hline Observation & 568 & 523 & 523 & 441 & 360 \\
\hline R-squared & 0.585 & 0.589 & 0.608 & 0.620 & 0.642 \\
\hline F-Statistic & $13.61 * * *$ & $13.86 * * *$ & $16.46^{* * * *}$ & $17.00^{* * *}$ & $84.04 * * *$ \\
\hline \multicolumn{4}{c}{ Standard errors are in parenthesis; $* * * p<0.01, * * p<0.05, * p<0.1$} \\
\hline
\end{tabular}

Analyzing Table 3 , it is obvious that the variables ea, ei, es (measuring employment in Agriculture, Industry, and Service) have a positive influence on trade unions on Model 1, but this effect is negative on Models 2, 3, and 5, and all of these fundings have low levels of significance. In Model 4, the natural logarithmic form of ei (LNei) has a positive and significant effect on the natural logarithmic form of the dependent variable tupe (LNtupe), the percentage of employers who are members of trade unions, the other variable that has been transformed into the natural logarithmic form es (LNes), and the variable ei transformed into the natural logarithm (LNei). The number of workers in the industrial sector impacts the number of trade union members, but employees in other sectors have a lower likelihood of influencing trade union membership.

The second set of variables, $f d i, g d p d, g d p d$, igdpd, are not significant in Model 1 and 2; also, the converted logarithmic forms for these variables are not significant in Model 4. Furthermore, in Model 3, the natural logarithm form of $f d i$ and gdpd (LNfdi, LNgdpd) have a negative influence on trade unions, but only LNfdi is significant; in this model, gdpg and igdpd have a positive effect, and these results are significant. In Model 5, both $f d i$ and $g d p d$ have a negative effect on LNtupe, but only fdi is significant. Furthermore, in this model, gdpg has a positive and significant influence on trade unions, but $i g d p$ has a negative and non-significant effect on trade unions. Based on these data, we infer that FDI has a negative impact on trade union membership, whereas a rise in inflation increases the number of trade union members.

Except for Model 5, ave has a negative and insignificant influence on all models in the following group. The variable $m v a$ has a positive effect on all models but is only significant on Models 1, 2, and 5. In trade union memberships, the last variable in this category, svag, has a positive and highly significant level. They demonstrate that increasing the valueadded per worker in service increases union membership.

Finally, in all models, uae and its natural logarithmic counterpart LNuae have a negative and substantial influence on the proportion of workers who are union members (except Model 4, in which this variable is not significant). The variable uie has a negative effect on all of the models, but only in Models 3 and 4 in its natural logarithmic form. Furthermore, the variable ube has a negative influence on the trade union on all models and is significant on Models 1 and 5 in their original form, as well as Model 2 in its modified logarithmic version. Lastly, in all models, the variables utilo and wsw are positively connected, with high significant values, to trade unions (besides Model 3 in the transformed variable $L N w s w$, which is not significant). In conclusion, a rise in unemployment in the three sectors would reduce the number of trade union members, but an increase in earnings and salaries will enhance union involvement.

\section{CONCLUSIONS}

The study subjects in this article concentrate on the macroeconomic policies of OECD nations in order to impact trade union rates. Because the community developed by these nations presently accounts for $80 \%$ of global GDP, determining the results of trade union movements for these countries will provide a large fraction of the overall variations of trade unions worldwide. Many studies on the issue reveal a strong correlation between salaries and trade union membership; also, unemployment rates and worker productivity are closely connected with trade unions. Similarly, when evaluating the influence of macroeconomic measures on trade union memberships, we came to roughly the same conclusions.

This analysis confirmed that in the OECD countries, employers in the manufacturing (industry) sector are the most influential force in terms of the rate of trade union membership when compared to other economic sector employers. It is important to note that the OECD countries are considered developed countries, with the majority of employers concentrated in the manufacturing (industry) sector. Increasing the net flow of FDI will reduce trade union membership due to trade openness, which impacts pay increases and improves working conditions. Another conclusion drawn from this article is that productivity in the service industry per worker is positively connected with the rate of trade union membership, implying that salaries should be raised when productivity rises because otherwise, trade unions would expand. Last but not least, increased unemployment in economic sectors would reduce trade union membership; this might be due to discouragement and depressed unemployment, in which people do not want to join in trade unions. On the other hand, pay and salary increases simply drive a growth in trade unions, with the logic that as long as employees obtain what they want, they will seek for something more.

Identifying the factors that influence the trade union in developing countries should be a very intriguing analysis, especially in cases like Kosovo. However, we did not include them in our research due to a lack of data for specific characteristics in some developing nations. Further researchers can use these econometric models to analyze the factors affecting trade unions in developing countries, adding more value to this subject.

\section{REFERENCES}

[1] Kearney, R.C., Mareschal, P.M. (2017). Labor Relations in the Public Sector. Fifth Edition.

[2] Blanchard, O.J., Summers, L.H. (1986). Hysteresis and the European unemployment problem. NBER Macroecon. Annu., 1: 15-78. https://doi.org/10.1086/654013

[3] Turnbull, P. (2003). What do unions do now? Journal of Labor Research, 24(3): https://doi.org/10.1007/s12122-003-1010-5

[4] Ramjas. (1989). Impact of trade unions on productivity: A study of the Indian chemical industry. Vikalpa J. Decis. 
Makers,

14(2):

$13-18$.

https://doi.org/10.1177/0256090919890203

[5] Oswald, A.J. (1982). Trade unions, wages and unemployment: What can simple models tell us? Oxf. Econ. Pap., 34(3): 526-545. https://doi.org/10.1093/oxfordjournals.oep.a041569

[6] Bowdler, C., Nunziata, L. (2007). Trade union density and inflation performance: Evidence from OECD panel data. Economica, 74(293): 135-159. https://doi.org/10.1111/j.1468-0335.2006.00532.x

[7] Freeman, R.B., Nickell, S. (1988). Labour market institutions and economic performance. Econ. Policy, 3(6): 63. https://doi.org/10.2307/1344504

[8] Derber, M., Dickman, H. (1989). Industrial democracy in America: Ideological origins of national labor relations policy. Ind. Labor Relations Rev., 42(3): 460. https://doi.org/10.2307/2523403

[9] De Groot, H.L.F. (2001). Unemployment, growth, and trade unions. Growth Change, 32(1): 69-91. https://doi.org/10.1111/0017-4815.00150

[10] Daveri, F., Tabellini, G. (2000). Unemployment, growth and taxation in industrial countries. Econ. Policy, 30: 47104. https://doi.org/10.1111/1468-0327.00057

[11] Addison, J.T., Hirsch, B.T. (1989). Union effects on productivity, profits, and growth: Has the long run arrived? J. Labor Econ., 7(1): 72-105. https://doi.org/10.1086/298199

[12] Bean, C., Crafts, N. (1945). British economic growth since 1945: Relative economic decline ... and renaissance? Economic Growth in Europe Since, 131172.

[13] Van Reenen, J. (1996). The creation and capture of rents: wages and Innovation in a Panel of U.K. Companies. Q. J. Econ., 111(1): 195-226. http://dx.doi.org/10.2307/2946662

[14] Wrigley, C. (2002). British Trade Unions Since 1933.

[15] Aldcroft, D.H., Oliver, M.J. (2017). Trade Unions and the Economy: 1870-2000.

[16] Motyovszki, G. (2012). The Effect of Trade Union Density on Inflation Performance in OECD Countries, no. 2007.

[17] Choi, M. (2001). POLITICAL ECONOMY Threat Effect of Foreign Direct Investment on Labor Union.

[18] Walters, M., Lawrence, M. (2003). How unions help all workers. Econ. Policy Inst.

[19] Ng, I., Mccallum, J (1989). Trade unions, economic growth and politics. J. Ind. Relations, 31(3): 372-384. https://doi.org/10.1177/002218568903100304

[20] Ünal, E., Köse, N. (2018). The impact of workdays lost to strikes on wage growth in Turkey. J. Econ. Struct., 7(1) https://doi.org/10.1186/s40008-018-0108-0

[21] Mwamadzingo, M., Chinguwo, P. (2015). Productivity improvement and the role of trade unions. A Workers' Education Manual.

[22] Bryson, A., Forth, J. (2016). The added value of trade unions. A review for the TUC of existing research.

[23] Barth, E., Dale-olsen, H., Bryson, A. (2017). DISCUSSION PAPER SERIES Union Density, Productivity and Wages Union Density, Productivity and Wages, 11111.

[24] International Labour Organization, The role of trade unions in workers' education: The key to trade union capacity building, no. October, 2007.

[25] Stevenson, H., Milner, A., Winchip, E. (2018). Education Trade Unions for the Teaching Profession: Strengthening the capacity of education trade unions to represent teachers' professional needs in social dialogue.

[26] Merdad, H., Renaud, M. (2020). State of legislative and normative art in the fields of the environment, health and security of European electrical and electronic equipment. Eur. J. Electr. Eng., 22(4-5): 293-300. https://doi.org/10.18280/ejee.224-501 